IN PRAISE OF RISK 



\section{In Praise of Risk}

Anne Dufourmantelle

Translated by Steven Miller

F O R D H M UN IVERS ITY PRESS

New York 2019 
Copyright (C) 2019 Fordham University Press

All rights reserved. No part of this publication may be reproduced, stored in a retrieval system, or transmitted in any form or by any means-electronic, mechanical, photocopy, recording, or any other-except for brief quotations in printed reviews, without the prior permission of the publisher.

This book was originally published in French as Anne Dufourmantelle, Éloge du risque, Copyright (C) 201 I, 2014 Editions Payot \& Rivages.

Cet ouvrage, publié dans le cadre d'un programme d'aide à la publication, bénéficie de la participation de la Mission Culturelle et Universitaire Française aux Etats-Unis, service de l'Ambassade de France aux EU.

This work, published as part of a program of aid for publication, received support from the Mission Culturelle et Universitaire Française aux Etats-Unis, a department of the French Embassy in the United States.

Fordham University Press has no responsibility for the persistence or accuracy of URLs for external or third-party Internet websites referred to in this publication and does not guarantee that any content on such websites is, or will remain, accurate or appropriate.

Fordham University Press also publishes its books in a variety of electronic formats. Some content that appears in print may not be available in electronic books.

Visit us online at www.fordhampress.com.

Library of Congress Cataloging-in-Publication Data available online at https://catalog.loc.gov.

Printed in the United States of America 
to Clara, Gabriel, and Maud 
